\title{
Eläinten välinen vaihtelu rehun hyväksikäytössä ayrshire ensikoilla
}

\author{
Mäntysaari Päivi ${ }^{1}$, Anna-Elisa Liinamo ${ }^{2}$ ja Esa Mäntysaari ${ }^{2}$ \\ ${ }^{1}$ MTT, Kotieläintuotannon tutkimus, 31600 Jokioinen, etunimi.sukunimi@mtt.fi \\ ${ }^{2}$ MTT, Biotekniikka-ja elintarviketutkimus,31600 Jokioinen, etunimi.sukunimi@mtt.fi
}

\section{Tiivistelmä}

Rehukustannus muodostaa suuren osan maidontuotannon kustannuksista, siksi lehmien rehun hyväksikäytöllä on ratkaiseva vaikutus maidontuotannon kannattavuuteen. Myös ympäristön näkökulmasta on lehmien rehun hyväksikäytöllä merkitystä, koska sillä on vahva yhteys ravinne- ja kasvihuonekaasujen päästöihin. Lehmien rehun hyväksikäyttöä ja siinä esiintyvää fenotyyppistä vaihtelua tarkasteltiin Rehtijärven ASMO-karjasta vuosina 2006 - 2009 kerätyn aineiston pohjalta. Aineisto käsitti kaikkiaan 145 ayrshire ensikkoa, joilta oli 3752 viikkohavaintoa. Ensikoilta mitattiin tuotos-. syönti-, paino- ja kuntotiedot poikimisesta laktaatioviikolle 30 asti. Kaikkia eläimiä ruokittiin yhtenevästi. Lehmät saivat vapaasti seosrehua, joka koostui ensimmäisen sadon nurmisäilörehusta sekä kotoisesta väkirehusta. Rehun hyväksikäyttömittareina käytettiin tuotosta syötyä energiayksikköä kohti (=EKM/ME) sekä ns. energianmuuntoyhtälön residuaalia (Residual Energy Intake, REI). REI laskettiin vähentämällä syödystä energiasta maidontuotantoon ja ylläpitoon tarvittava energia sekä painonmuutoksen energian tarve tai saanti joko energiatarvesuositusten mukaan laskettuna $\left(=\mathrm{REI}_{1}\right)$ tai regressiomallilla itse aineistosta laskettuna $\left(=\mathrm{REI}_{2}\right)$. Lehmien sisäinen ja välinen vaihtelu rehun hyväksikäytössä estimoitiin käyttäen SAS Mixed-mallia. Eläinten välisiä fenotyyppisiä eroja pyrittiin kuvaamaan myös luokitteluin. Rehun hyväksikäyttömittareiden yhteyksiä lehmien tuotos-, syönti- ja painotekijöihin kartoitettiin.

Aineiston lehmien lypsivät keskimäärin $28,8 \mathrm{~kg}$ EKM päivässä ja söivät 18,7 kg kuiva-ainetta, mikä vastasi 218,6 ME MJ/pv. Keskielopaino oli suurimmalla lehmällä $752 \mathrm{~kg}$ ja pienimmällä $443 \mathrm{~kg}$, keskimääräinen paino aineiston lehmillä oli $586 \mathrm{~kg}$. Keskimääräiset rehun hyväksikäyttöarvot olivat 0,133 (SD=0,02) EKM kg/ME MJ, 3,2 (SD=23,3) ME MJ/pv $\left(\mathrm{REI}_{1}\right)$ ja $0.00 \quad(\mathrm{SD}=20,5) \mathrm{ME} \mathrm{MJ} / \mathrm{pv}$ $\left(\mathrm{REI}_{2}\right)$. Lasketuissa viikoittaisissa rehun hyväksikäyttöarvoissa havaittiin vaihtelua lypsykauden vaiheen mukaan. Lypsykauden vaiheen vaikutus näkyy selvimmin EKM/ME-arvoissa, mikä on ymmärrettävää. sillä ko. mittarissa ei pystytä erottamaan elopainon muutoksen vaikutuksia. Vaihtelu REI-arvoissa voi viitata siihen, että energian hyväksikäytössä olisi vaihtelua lypsykauden eri vaiheissa, osittain tämä kuitenkin lienee seurausta vaikeudesta arvioida painonmuutosta lypsykauden ensimmäisinä viikkoina.

Aineiston perusteella todettiin lehmien välillä olevan fenotyyppistä vaihtelua rehun hyväksikäytössä. Eläimen osuus kokonaisvaihtelusta oli 35\% (REI $), 30 \%\left(\mathrm{REI}_{2}\right)$ ja $50 \%(\mathrm{EKM} / \mathrm{ME})$. Kun arviointiperusteena oli EKM-tuotos energiansaanti yksikköä kohti, oli hyväksikäytön paraneminen liitoksissa paitsi alhaisempaan syöntiin $(r=-0,51)$ ja korkeampaan tuotokseen $(r=0,58)$ niin myös lisääntyneeseen painonpudotukseen $(r=-0,50)$. Arvioitaessa hyväksikäyttöä REI:llä oli parempi hyväksikäyttö liitoksissa alhaisempaan syöntiin ( $\left.\mathrm{REI}_{1}: \mathrm{r}=0.60 ; \mathrm{REI}_{2}: \mathrm{r}=0.74\right)$, mutta ei elopainonmuutokseen $\left(\mathrm{REI}_{1}: \mathrm{r}=0.13 ; \mathrm{REI}_{2}: \mathrm{r}=0.00\right)$.

Asiasanat: rehun hyväksikäyttö, ayrshire, ensikot 


\section{Johdanto}

Rehukustannus muodostaa suuren osan maidontuotannon kustannuksista, siksi lehmien rehun hyväksikäytöllä on ratkaiseva vaikutus maidontuotannon kannattavuuteen. Myös ympäristön näkökulmasta on lehmien rehun hyväksikäytöllä merkitystä, koska sillä on vahva yhteys ravinne- ja kasvihuonekaasujen päästöihin. Perinteisesti jalostusohjelmissa on keskitytty tuotanto-ominaisuuksien jalostukseen (esim. Miglior, ym. 2005). Tämä on johtanut tuotosten lisääntymiseen, minkä periaatteessa tulisi johtaa parantuneeseen rehun hyväksikäyttöön ylläpitorehun jakautuessa suuremmalle tuotosmäärälle. Suuria muutoksia rehun hyväksikäytössä ei kuitenkaan ole mitattu, sillä tuotostason jalostus on johtanut myös elopainon nousuun. Lisäksi tuotosten nousu on aiheuttanut ruokinnallisia muutoksia (ruokintataso ja dieetin väkevyys), joilla on ollut negatiivinen vaikutus rehun hyväksikäytölle (Huhtanen, 1998). Rehun hyväksikäytön sisällyttäminen jalostusvalintaan edellyttää, että kyseisessä ominaisuudessa on fenotyyppistä ja geneettistä vaihtelua ja ominaisuus voidaan luotettavasti mitata. Ayrshire lehmillä esiintyvää vaihtelua rehun hyväksikäytössä ei ole selvitetty. Colemanin ym. (2010) ja Legatesin (1990) tutkimuksissa mitattiin eroja rehun hyväksikäytössä eri genotyyppiä edustavilla Holstein lehmillä. Tämän tutkimuksen tavoitteena oli selvittää EKM/ME:n ja energianmuuntoyhtälön residuaalin (Residual Energy Intake, REI) käyttöä rehun hyväksikäyttömittarina sekä kartoittaa yhtenevästi ruokituilla geneettisesti korkeatasoisilla ayrshire ensikoilla esiintyvää fenotyyppistä vaihtelua rehun hyväksikäytössä ensimmäisen lypsykauden aikana.

\section{Aineisto ja menetelmät}

Tutkimuksen aineisto kerättiin MTTn Rehtijärven ASMO-karjassa vuosina 2006 - 2009 poikineilta ayrshire ensikoilta. Ensikoilta mitattiin tuotos-. syönti-, paino- ja kuntotiedot poikimisesta laktaatioviikolle 30 asti. Kaikkiaan aineisto sisälsi 3752 viikkohavaintoa 145 ensikolta. Kaikilla aineiston lehmillä oli yhtenevä ruokinta. Lehmät saivat vapaasti seosrehua, joka koostui ensimmäisen sadon nurmisäilörehusta sekä kotoisesta väkirehusta. Väkirehuseoksia oli kaksi. Väkirehuseos A sisälsi (g/ kg) ohraa 301, kauraa 300, melassileikettä 109, rypsirouhetta 259 ja vitamiineja ja kivennäistä 31. Väkirehuseos B sisälsi $(\mathrm{g} / \mathrm{kg}$ ) ohraa 158, kauraa 140, melassileikettä 118, rypsirouhetta 554 ja vitamiineja ja kivennäistä 30. Lehmän rehuannoksen väkirehutaso määräytyi säilörehun D-arvon ja lypsykauden vaiheen perusteella. D-arvon ollessa $680 \quad-700 \mathrm{~g} / \mathrm{kg} \mathrm{ka}$ oli rehuannoksen väkirehupitoisuus kuiva-aineessa $520 \mathrm{~g} / \mathrm{kg}$ laktaatiopäivinä 1-150, minkä jälkeen väkirehupitoisuus putosi $450 \mathrm{~g} / \mathrm{kg}$ ka. Kuitenkin mikäli säilörehun D-arvo lisääntyi tai laski edellä annetuista arvoista väkirehun pitoisuus seosrehussa lisääntyi tai laski $20 \mathrm{~g} / \mathrm{kg}$ ka jokaista $10 \mathrm{~g} / \mathrm{kg}$ ka Darvon nousua tai laskua kohti. Väkirehun A ja B suhteellinen osuus väkirehusta määräytyi väkirehuannokselle asetetun valkuaistavoitteen mukaan. Lypsykauden alussa (1-150) väkirehun valkuaispitoisuutena oli $195 \mathrm{~g} / \mathrm{kg}$ ka ja loppulypsykaudella $185 \mathrm{~g} / \mathrm{kg} \mathrm{ka}$.

Lehmien maitotuotokset mitattiin kahtena päivänä viikossa. Maidon valkuais-, rasva- ja laktoosianalyysejä varten otettiin lypsykauden alussa maidosta 8 viikon ajan viikoittaiset maitonäytteet. Myöhemmässä laktaatiovaiheessa maidon koostumus analysoitiin kerran kuukaudessa koelypsypäivinä. Näytteet analysoitiin Valion Seinäjoen laboratoriossa. Lehmien rehunkulutus mitattiin päivittäin. Säilörehusta otettiin rehunäytteet kaksi kertaa ja väkirehusta kerran viikossa. Rehuanalyysit tehtiin MTT:n laboratoriossa standardimenetelmin. Säilörehun orgaanisen aineen sulavuus laskettiin orgaanisen aineen in vitro pepsiini-sellulaasiliukoisuuden perusteella (Huhtanen ym. 2006). Rehujen rehuarvot laskettiin Rehutaulukoissa (MTT, 2006) esitettyjen laskentaperusteiden mukaan. Väkirehun ja säilörehun kemiallinen koostumus ja rehuarvot on esitetty Taulukossa 1.

Lehmät punnittiin 8 ensimmäisen lypsyviikon ajan viikoittain, seuraavan 8 viikon ajan joka toinen viikko ja tämän jälkeen kerran neljässä viikossa.. Lehmien kuntoluokka arvioitiin asteikolla 1-5 (Edmonson ym. 1989) koko aineiston keruun ajan kahden viikon välein. 
Taulukko 1. Rehujen koostumus ja rehuarvot (ka \pm S.D.)

\begin{tabular}{lccr}
\hline & Säilörehu $^{1}$ & Väkirehu A & \multicolumn{1}{c}{ Väkirehu B } \\
\hline Kuiva-aine, g/kg & $258,8 \pm 39,8$ & $890,7 \pm 4,9$ & $889,0 \pm 3,0$ \\
Kuiva-aineessa, g/kg & & & \\
$\quad$ Tuhka & $83,6 \pm 9,8$ & $75,5 \pm 1,9$ & $85,5 \pm 2,6$ \\
$\quad$ Raakavalkuainen & $159,9 \pm 19,9$ & $187,8 \pm 8,3$ & $249,3 \pm 6,8$ \\
$\quad$ Raakarasva & $50,8 \pm 5,7$ & $70,0 \pm 2,5$ \\
NDF & $505,9 \pm 29,2$ & $240,9 \pm 11,4$ & $258,2 \pm 8,4$ \\
$\quad$ D-arvo & $702 \pm 23$ & & \\
Rehuarvot kuiva-aineessa & & & \\
ME, MJ/kg & $11,2 \pm 0,4$ & $12,1 \pm 0,08$ & $12,0 \pm 0,05$ \\
OIV, g/kg & $86,7 \pm 2,4$ & $119,9 \pm 1.86$ & $129,7 \pm 1,57$ \\
\hline
\end{tabular}

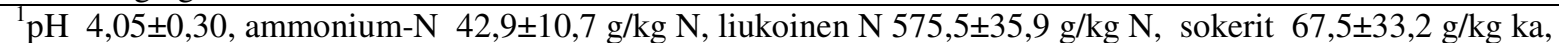
maitohappo 53,0 $\pm 18,8 \mathrm{~g} / \mathrm{kg}$ ka, etikkahappo $16,1 \pm 3,5 \mathrm{~g} / \mathrm{kg} \mathrm{ka}$, propionihappo $0,33 \pm 0,47 \mathrm{~g} / \mathrm{kg}$ DM, voihappo $0,007 \pm 0,02 \mathrm{~g} / \mathrm{kg} \mathrm{ka}$

Ensikoille laskettiin viikoittainen keskimääräinen rehunsyönti ja maitotuotos. Viikoittainen elopaino määritettiin punnittujen painojen perusteella käyttäen Wilminkin (1987) yhtälöä kullekin lehmälle. Kunkin laktaatioviikon kuntoluokka määritettiin arvioitujen kuntoluokkien perusteella lasketusta yksilökohtaisesta kolmannen asteen regressioyhtälöstä. Lehmien viikoittainen energiatase laskettiin syödyn energian ja ylläpitoon ja maidontuotantoon käytetyn energia erotuksena. Ylläpitoon ja maidontuotantoon käytetty energia laskettiin Rehutaulukoissa (MTT, 2006) annetuiden tarvenormien mukaan. Rehun hyväksikäyttömittareina käytettiin EKM- tuotosta syötyä energiayksikköä kohti (=EKM/ME) sekä ns. energianmuuntoyhtälön residuaalia (Residual Energy Intake, REI). REI laskettiin vähentämällä syödystä energiasta maidontuotantoon, ylläpitoon ja kasvuun tarvittava energia sekä lisäämällä painonpudotusta vastaava energia joko energiatarvesuositusten (MTT, 2006) mukaan laskettuna (=REI $)_{1}$ tai regressiomallilla itse aineistosta laskettuna $\left(=\mathrm{REI}_{2}\right)$.

Lehmien sisäinen ja lehmien välinen vaihtelu rehun hyväksikäytössä arvioitiin käyttäen SAS Mixed-mallia. Eläinten välisiä fenotyyppisiä eroja pyrittiin kuvaamaan myös luokitteluin. Lehmille laskettiin keskimääräinen $\mathrm{EKM} / \mathrm{ME}$ ja $\mathrm{REI}_{2}$-arvo laktaatioviikoilla 2-30, jonka perusteella lehmät luokiteltiin parhaisiin (paras neljännes) ja heikoimpiin (heikoin neljännes) rehun hyväksikäyttäjiin. Rehun hyväksikäyttömittareiden yhteyksiä lehmien tuotos-, syönti- ja painotekijöihin tarkasteltiin korrelaatioiden avulla.

\section{Tulokset ja tulosten tarkastelu}

Lehmien keskimääräinen EKM-tuotos laktaatioviikoilla $2-30$ oli $28,8 \mathrm{~kg} / \mathrm{pv}$ vaihdellen 16,9 kilosta 38,1 kiloon päivässä (Taulukko 2). Lehmät söivät keskimäärin $18.7 \mathrm{~kg} \mathrm{ka/pv}$, mikä vastasi 219 ME MJ/pv. Sekä tuotos- että syöntikäyrät olivat hyvin tasaisia (Kuva 1), mikä on tyypillistä ensikoille (Mäntysaari \& Mäntysaari, 2010). Keskielopaino oli suurimmalla lehmällä $752 \mathrm{~kg}$ ja pienimmällä 443 $\mathrm{kg}$, keskimäärin aineiston lehmät painoivat $586 \mathrm{~kg}$. Ensikkoaineistosta johtuen myös painon pudotus lypsykauden alussa oli kohtuullinen ja elopaino kääntyi nousuun keskimäärin jo kuudennella laktaatioviikolla (Kuva 2). Tarkastelujakson aikana ensikot lisäsivät painoaan keskimäärin $47 \mathrm{~kg}$. Koska kuntoluokassa ei havaittu suuria muutoksia (Kuva 2), voidaan olettaa, että ensikoiden painonlisäys on ollut etupäässä kasvua ja vähemmän rasvavarastojen kertymistä. 
Taulukko 2. Tuotos-, syönti ja painotietojen keskiarvot (ka), hajonta (SD) sekä minimi- ja maximiarvot laskettuna lehmäkohtaisista keskiarvoista (lypsyviikot 2-30).

\begin{tabular}{lcccc}
\hline & ka & SD & Min & Max \\
\hline Maito, kg/pv & 28,2 & 3,71 & 16,9 & 38,1 \\
EKM yield, kg/pv & 28,8 & 3,58 & 18,4 & 39,5 \\
Maidon pitoisuudet, g/kg & & & & 5,17 \\
$\quad$ Rasva & 4,11 & 0,395 & 3,20 & 4,03 \\
$\quad$ Valkuainen & 3,52 & 0,183 & 3,04 & 5,00 \\
$\quad$ Laktoosi & 4,70 & 0,102 & 4,42 & 22,3 \\
Syönti, kg ka/pv & 18,7 & 1,69 & 14,7 & 11,6 \\
$\quad$ Säilörehu & 9,6 & 0,89 & 7,3 & 10,9 \\
Väkirehu & 9,1 & 0,83 & 7,1 & 4,27 \\
Energia, ME MJ/pv & 218,6 & 19,6 & 173,0 & 752 \\
Valkuainen, kg/pv & 3,35 & 0,35 & 2,53 & 1,052 \\
Elopaino, kg & 586 & 55,0 & 443 & 0,777 \\
Elopainonmuutos, kg/pv & & & & 3,90 \\
$\quad$ Viikot 2-6 & $-0,201$ & 0,351 & $-1,662$ & 0,030 \\
$\quad$ Viikot 7-30 & 0,290 & 0,154 & $-0,110$ & 2,26 \\
Kuntoluokka & 3,06 & 0,28 & $-0,094$ & \\
Kunnonmuutos, yksikköä/viikko & $-0,002$ & 0,016 & & \\
\hline
\end{tabular}

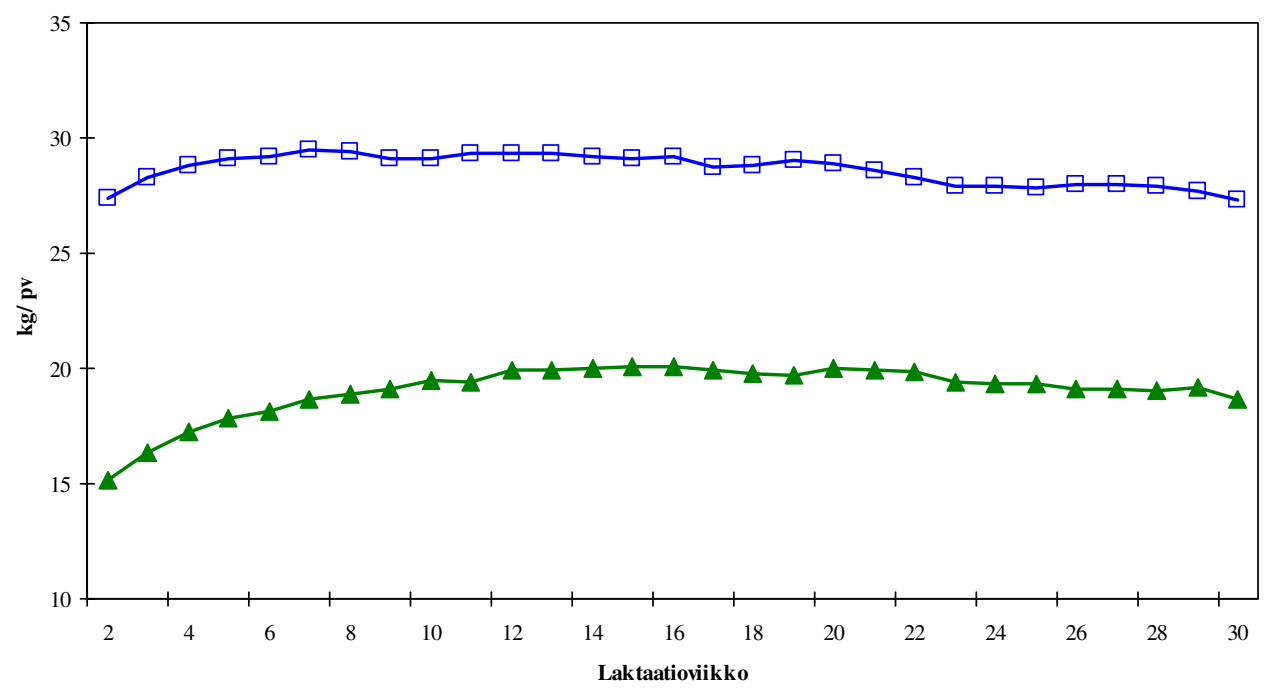

Kuva 1. Lehmien EKM-tuotos ( $\square)$ ja kuiva-ainesyönti ( $\Delta$ ).

Aineiston ensikot tuottivat keskimäärin 0,133 ( $\mathrm{SD}=0,02) \mathrm{kg}$ EKM $/ \mathrm{ME}$ MJ. Keskimääräinen rehun hyväksikäyttö (Taulukko 3) arvioituna $\mathrm{REI}_{1}: 11$ a oli 3,2 ( $\left.\mathrm{SD}=23,3\right) \mathrm{ME} \mathrm{MJ} / \mathrm{pv}$ ja $\mathrm{REI}_{2}: 11 \mathrm{a}$ odotetusti $0.0(\mathrm{SD}=20,3) \mathrm{ME} \mathrm{MJ} / \mathrm{pv}$, sillä $\mathrm{REI}_{2}$ perustui tästä aineistosta laskettuihin kertoimiin. Teoriassa keskimääräisellä lehmällä REI-arvon tulisi olla 0. Jos REI on negatiivinen, käyttää lehmä energiaa keskiarvoeläintä (joko populaation $\left(\mathrm{REI}_{1}\right)$ tai käytetyn aineiston $\left(\mathrm{REI}_{2}\right)$ ) tehokkaammin, jos taas REI on positiivinen, on lehmä keskimääräistä eläintä heikompi rehun hyväksikäyttäjä.

Taulukko 3. Lehmien rehun hyväksikäytön keskiarvo (ka) ja sen hajonta (SD) sekä eläinten sisäinen vaihtelu (SE) ja eläinten välisen vaihtelun osuus kokonaisvaihtelusta $\left(C^{2}\right)$.

\begin{tabular}{lllll}
\hline & $\mathrm{ka}$ & $\mathrm{SD}$ & $\mathrm{SE}$ & $\mathrm{C}^{21}$ \\
\hline $\mathrm{EKM} / \mathrm{ME}, \mathrm{kg} / \mathrm{ME} \mathrm{MJ}$ & 0.133 & 0.020 & 0.014 & 0.50 \\
$\mathrm{REI}_{1}, \mathrm{ME} \mathrm{MJ} / \mathrm{pv}$ & 3.2 & 23.3 & 18.8 & 0.35 \\
$\mathrm{REI}_{2}, \mathrm{ME} \mathrm{MJ} / \mathrm{pv}^{2}$ & 0.0 & 20.5 & 17.1 & 0.30 \\
\hline
\end{tabular}




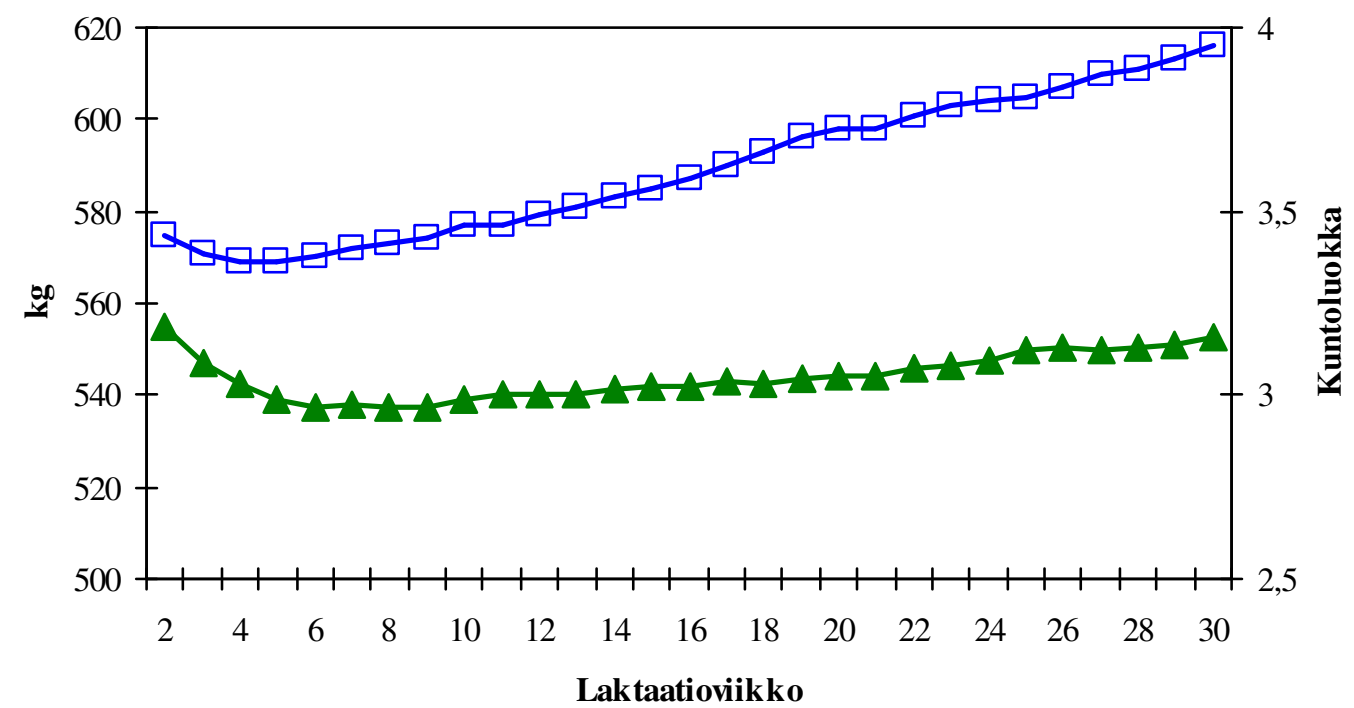

Kuva 2. Lehmien elopaino ( $\square)$ ja kuntoluokka ( $\Delta$ ).

Rehun hyväksikäytön viikoittainen vaihtelu on esitetty kuvassa 3. Lypsykauden vaiheen vaikutus näkyy selvimmin EKM/ME-arvoissa. Tämä on ymmärrettävää. sillä ko. mittarissa ei huomioida elopainon muutoksen vaikutuksia rehun hyväksikäyttöön. Lypsykauden alussa lehmät käyttävät kudosvarastojaan maidontuotantoon, jolloin luonnollisesti tuotos syötyä energiayksikkö kohti on korkeampi. Kudosvarastojen käyttöä kuvastavan energiataseen kehitys on esitetty kuvassa 3. Vaikka REI:n laskussa painonmuutoksen vaikutus on huomioitu, näkyi lypsykauden vaiheen vaikutus myös REI-arvoissa. Rehun hyväksikäyttö oli tehokkaampaa ensimmäisinä lypsyviikkoina myös arvioitaessa hyväksikäyttöä $\mathrm{REI}_{1}: 11$ ä tai $\mathrm{REI}_{2}: 11 \mathrm{la}$. Vastaava lypsykauden vaiheen vaikutus on havaittu myös muissa tutkimuksissa (Veerkamp \& Emmans, 1995). Tämä voi viitata siihen, että energian hyväksikäytössä olisi vaihtelua lypsykauden eri vaiheissa, osittain havaittu vaihtelu lienee kuitenkin seurausta vaikeudesta arvioida painonmuutosta ja sen koostumusta lypsykauden ensimmäisinä viikkoina (Tamminga ym., 1997).

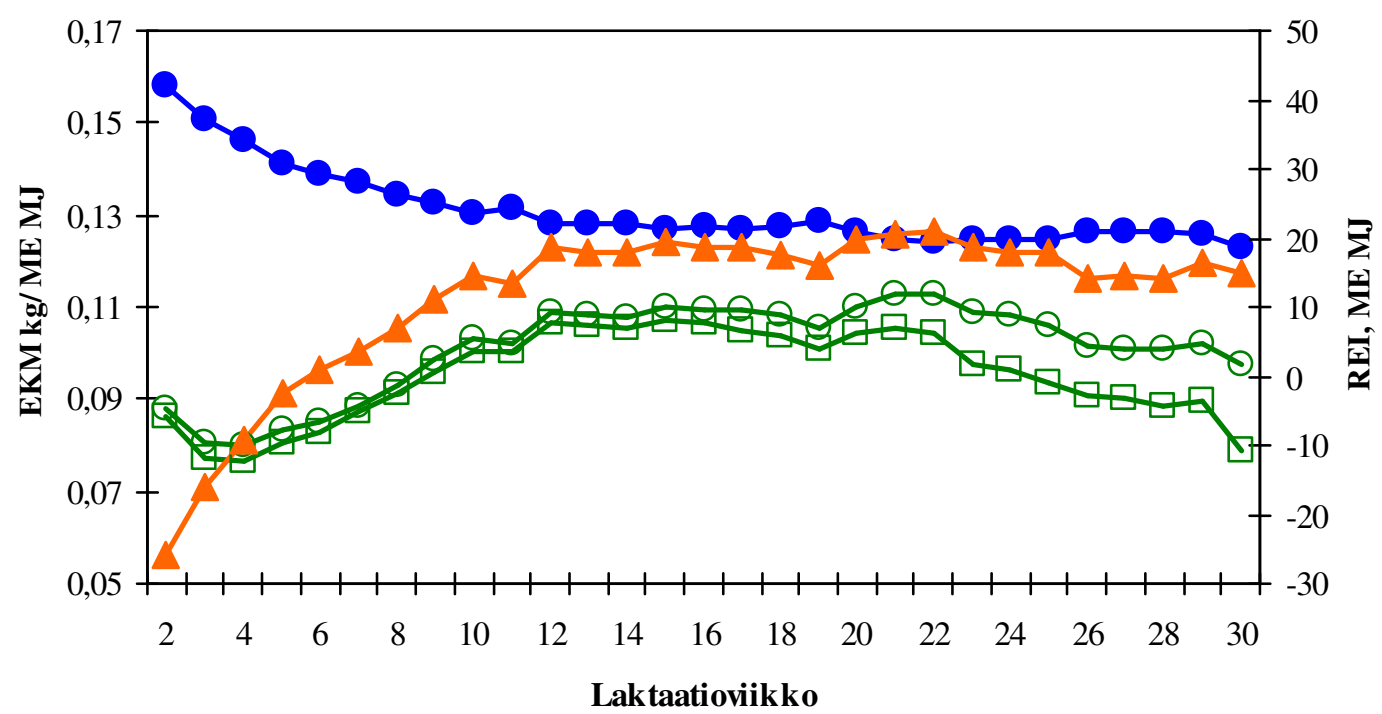

Kuva 3. Keskimääräinen viikoittainen energiatase $(\Delta)$ sekä rehun hyväksikäyttö mitattuna EKMtuotoksena syötyä energiaa kohti (•; EKM/ME ) energianmuuntoyhtälön residuaalina laskettuna tarvenormien mukaan $\left(\circ ; \mathrm{REI}_{1}\right)$ tai käytetystä aineistosta laskettuna $\left(\square ; \mathrm{REI}_{2}\right)$., 


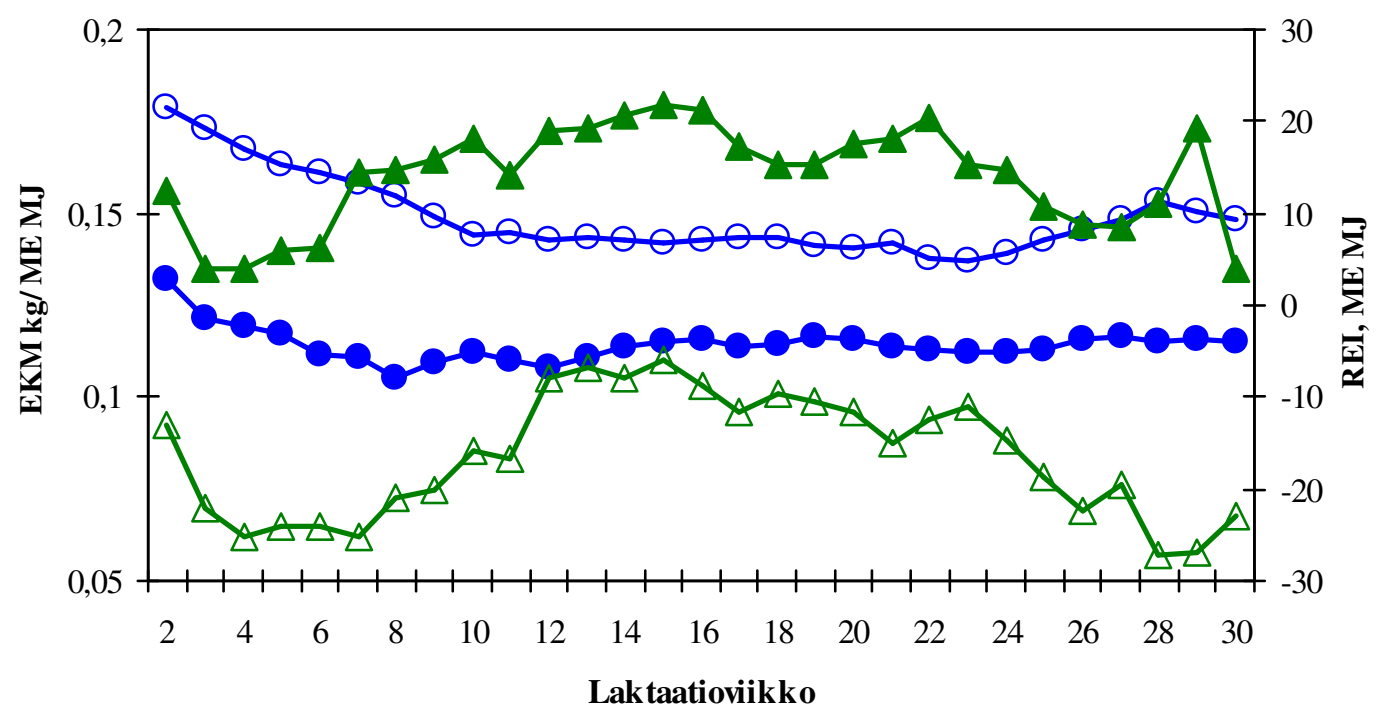

Kuva 4. Aineiston lehmistä parhaan ja heikoimman neljänneksen rehun hyväksikäyttö mitattuna $\mathrm{EKM} / \mathrm{ME}$ (paras $\circ$ ja heikoin $\bullet$ ) ja $\mathrm{REI}_{2}$ (paras $\Delta$ ja heikoin $\Delta$ ) laktaatioviikoilla 2-30.

Suuri osa viikoittaisten mittausten vaihtelusta oli eläimen sisäistä vaihtelua, mutta myös eläinten välinen vaihtelu oli merkittävää (Taulukko 3). Eläimen osuus kokonaisvaihtelusta oli $35 \%\left(\mathrm{REI}_{1}\right)$, $30 \%\left(\mathrm{REI}_{2}\right)$ ja 50\% (EKM/ME). Yksilöiden välisiä eroja rehun hyväksikäytössä kuvaa hyvin kuva 4, joissa on esitetty aineiston lehmistä parhaimman ja heikoimman neljänneksen rehun hyväksikäyttö tarkastelujaksolla.

Taulukossa 4 on rehun hyväksikäytön ja tuotos-, syönti- sekä painotietojen väliset korrelaatiot. Kun rehun hyväksikäytön arviointiperusteena oli EKM-tuotos energiansaanti yksikköä kohti, oli hyväksikäytön paraneminen liitoksissa paitsi alhaisempaan syöntiin $(\mathrm{r}=-0,51)$ ja korkeampaan tuotokseen $(\mathrm{r}=0,58)$ niin myös lisääntyneeseen painonmuutokseen $(\mathrm{r}=-0,50)$. Luonnollisesti EKM/ME on myös yhteydessä eläinten kokoon, niin että isoilla eläimillä suuremmasta ylläpitotarpeesta johtuen syödystä energiasta pienempi osa käytetään maidontuotantoon. Tämä tekee EKM/ME:stä taloudellisesti tarkastellen REI-mittoja suoremman maidontuotannon tehokkuuden mitan. Mitattaessa rehun hyväksikäyttöä taas REI-arvolla ei suuremman eläimen suurempi ylläpitotarve heikennä eläimen REI-arvoa. $\mathrm{REI}_{1}: 11$ ä mitattuna parempi hyväksikäyttö oli liitoksissa alhaisempaan syöntiin $\left(\mathrm{REI}_{1}\right.$ : $r=0.60)$, runsaampiin tuotoksiin $(r=-0,41)$, mutta ei voimakkaasti elopainonmuutokseen $\left(R^{2} I_{1}: r=0.13\right)$. Arvioitaessa hyväksikäyttöä $\mathrm{REI}_{2}$ :lla oli parantunut rehun hyväksikäyttö liitoksissa alhaisempaan syöntiin $(\mathrm{r}=0.74)$, mutta laskutavasta johtuen ei EKM-tuotokseen, elopainoon tai painonmuutokseen. Kaikkien hyväksikäyttömittareiden perusteella lisäsi maidon rasvapitoisuus maidontuotannon tehokkuutta.

Taulukko 4. Rehun hyväksikäyttömittareiden ja tuotos-, syönti- sekä elopainotekijöiden välisiä korrelaatioita.

\begin{tabular}{lccc}
\hline & EKM/ ME MJ & $\mathrm{REI}_{1}{ }^{2}$ & $\mathrm{REI}_{2}{ }^{3}$ \\
\hline EKM, kg/pv & 0,58 & $-0,41$ & 0,00 \\
Maidon rasva, g/kg & 0,39 & $-0,31$ & $-0,23$ \\
Maidon proteiini, g/kg & $-0,04$ & 0,08 & $-0,03$ \\
Syönti, kg ka/pv & $-0,51$ & 0,60 & 0,74 \\
Elopaino, kg & $-0,18$ & 0,08 & 0,00 \\
Elopianonmuutos, kg/pv & $-0,50$ & 0,13 & 0,00 \\
Kuntoluokka & $-0,12$ & 0,05 & $-0,09$ \\
Kuntoluokan muutos & $-0,17$ & 0,08 & 0,05 \\
\hline
\end{tabular}




\section{Johtopäätökset}

Tutkimuksessa rehun hyväksikäyttöä mitattiin EKM- tuotoksella syötyä energiayksikköä kohti (=EKM/ME) sekä ns. energianmuuntoyhtälön residuaalilla (Residual Energy Intake, REI). REI laskettiin vähentämällä syödystä energiasta maidontuotantoon, ylläpitoon ja kasvuun tarvittava energia sekä lisäämällä painonpudotusta vastaava energia joko energiatarvesuositusten mukaan laskettuna $\left(=\mathrm{REI}_{1}\right)$ tai regressiomallilla itse aineistosta laskettuna $\left(=\mathrm{REI}_{2}\right)$. Tutkimusaineiston ayrshire ensikoilla keskimääräiset rehun hyväksikäyttöarvot ( $\mathrm{ka}$ ja $\mathrm{SD}$ ) olivat 0,133 ( $\mathrm{SD}=0,02) \mathrm{EKM} \mathrm{kg/ME} \mathrm{MJ,} \mathrm{3,2}$ $(\mathrm{SD}=23,3) \mathrm{ME} \mathrm{MJ} / \mathrm{pv}\left(\mathrm{REI}_{1}\right)$ ja $0.00(\mathrm{SD}=20,5) \mathrm{ME} \mathrm{MJ} / \mathrm{pv}\left(\mathrm{REI}_{2}\right)$. Rehun hyväksikäytön kokonaisvaihtelusta eläinten välinen vaihtelua oli EKM/ME:ssa 50\%, REI $I_{1}$ :ssä 35\% ja $\mathrm{REI}_{2}$ :ssa 30\%. Ayrshire ensikoiden välillä siis mitattiin selvää fenotyyppistä vaihtelua rehun hyväksikäytössä, joten tältä osin on olemassa pohja jalostusvalinnalle. EKM/ME:n käyttöä rehun hyväksikäyttömittarina rajoittaa sen voimakas yhteys elopainon muutokseen, jolloin runsas 'lihoista lypsäminen' lypsykauden alussa johtaa korkeampiin EKM/ME arvoihin. REI-laskuissa on energian tarve/saanti painonmuutoksesta huomioitu, silti myös viikoittaisissa REI-arvoissa havaittiin vaihtelua lypsykauden vaiheen mukaan. Tämä voi viitata siihen, että energian hyväksikäytössä olisi vaihtelua lypsykauden eri vaiheissa, osittain havaittu vaihtelu lienee kuitenkin seurausta vaikeudesta arvioida painonmuutosta ja sen koostumusta lypsykauden ensimmäisinä viikkoina.

\section{Kirjallisuus}

Coleman, J., Berry, D.P., Pierce, K.M., Brennan, A. \& Horan, B.. 2010. Dry matter intake and feed efficiency profiles of 3 genotypes of Holstein-Friesian within pasture-based systems of milk production. J. Dairy Sci. 93:4318-4331

Edmonson, A. J., Lean, I.J., Weaver, L.D., Farver, T. \& Webster, G.. 1989. A body condition scoring chart for Holstein dairy cows. J. Dairy Sci. 72:68-78.

Huhtanen, P. 1998. Supply of nutrients and productive responses in dairy cows given diets based restrictively fermented silage. Agric. and Food Sci. in Finland. 7:219 - 250.

Huhtanen, P., Nousiainen, J. \& Rinne, M. 2006. Recent developments in forage evaluation with special reference to practical applications. Agricultural and Food Science 15: 293-323.

Miglior, F., Muir, B.L. \& Van Doormaal, B.J.. 2005. Selection indices in Holstein cattle of various countries. J. Dairy Sci. 88:1255-1263

MTT, 2006. Rehutaulukot ja ruokintasuositukset [online]. Jokioinen: MTT Agrifood Research Finland. http://www.mtt.fi/rehutaulukot/. URN:NBN:fi-fe20041449.

Mäntysaari, P. \& Mäntysaari, E.A. 2010. Predicting early lactation energy balance in primiparous Red Dairy Cattle using milk and body traits. Acta Agric. Scand., Sect. A, 60:79-87

Mäntysaari, P., Liinamo, A.-E. \& Mäntysaari, E.A. 2011. Energy efficiency and its relationship with milk, body, and intake traits and energy status among primiparous Nordic Red Dairy Cattle. Submitted

Tamminga, S., Luteijn, P.A. \& Meijer, R.G.M. 1997. Changes in composition and energy content of liveweight loss in dairy cows with time after parturition. Livest. Prod. Sci. 52:31 - 38 .

Veerkamp, R.F. \& Emmans, G.C. 1995. Sources of genetic variation in energetic efficiency of dairy cows. Livest. Prod. Sci. 44:87-97.

Wilmink, J.B.M. 1987. Adjustment of test-day milk, fat and protein yield for age, season and stage of lactation. Livest. Prod. Sci. 16:335-348. 